\title{
Occurrence, distribution and absorption of provitamins A
}

\author{
By S. Y. 'Thомpson, Department of Nutrition, National Institute for Research in \\ Dairying, Shinfield, Reading
}

The term vitamin A activity has been used for many years to refer to all substances that can restore growth and other functions in experimental animals or man subsisting on a vitamin A-deficient diet. Among the many vitamin A-active substances are the carotenoids, whose importance becomes obvious when it is remembered that they are the ultimate source of all vitamin $\mathrm{A}$ in nature. In this paper the term provitamins is restricted to the biologically active carotenoids. For many animals, in particular ruminants and herbivores, these provitamins are the only source of vitamin A activity. For omnivores such as man the proportion of the vitamin $A$ intake derived from provitamins varies widely. Carnivores get most of their vitamin A preformed; there is doubt if some of them, the cat in particular (Gershoff, Andrus \& Hegsted, I954), can convert carotene into vitamin A.

This paper deals mainly with the importance of the provitamins in human nutrition. First the various forms and their occurrence in plants and in animals are considered, then the importance of the vegetable and fruit sources in various parts of the world, and finally the many factors influencing absorption and utilization of the provitamins.

\section{Carotenoid provitamins}

In general to possess vitamin $A$ activity a provitamin must have at least one $\beta$-ionone ring and a polyene side-chain.

$\beta$-Carotene and its provitamin derivatives. $\beta$-Carotene is the most important provitamin for two reasons. First, it is present in many plants that are important to man and his livestock; secondly, it possesses two $\beta$-ionone rings and polyene side-chains and is the provitamin $\mathrm{A}$ with the greatest activity. The $\beta$-apocarotenals, first prepared in the laboratory by Karrer \& Solmssen (I937), have been found in nature by Winterstein, Studer \& Rüegg (1960) and postulated to be the degradation products formed if terminal oxidation of the $\beta$-carotene molecule is the pathway for the conversion into vitamin A (Glover $\&$ Redfearn, 1954). The $\beta$-apocarotenals have around $50 \%$ of the activity of $\beta$-carotene when given by mouth (Karrer \& Solmssen, 1937; Glover \& Redfearn, 1954; Marusich, De Ritter, Vreeland \& Krukar, 1960)

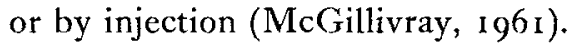

Oxidation that opens both rings destroys activity but, when only one ring is attacked, $\beta$-hydroxycarotene and $\beta$-semicarotenone are formed. They have half the activity of $\beta$-carotene. The 5,3,6-mono- and 5,6-5',6'-di-epoxide have been found in plants (Karrer, Jucker, Rutschmann \& Steinlin, 1945 ) and are vitamin A precursors despite alteration to the $\beta$-ionone ring, the explanation being that the body can convert the epoxide into $\beta$-carotene. Another active oxide of $\beta$-carotene found in nature is mutatochrome; it has one intact $\beta$-ionone ring and the other changed to a furanoid structure. Hydrogenation, as would be used in the hardening of vegetable fats, 
completely destroys the activity of $\beta$-carotene. Dehydrogenation also causes loss of activity.

$\alpha$-and $\gamma$-carotenes. Since these compounds have only one $\beta$-ionone ring, they have only half the activity of $\beta$-carotene. Little is known about their derivatives, but the monoepoxides are active and occur in plants (Karrer et al. 1945). The apocarotenes are inactive, since degradation begins at the $\beta$-ionone ring and $\alpha$-apocarotenals are formed.

Carotenoids containing oxygen. Cryptoxanthin, 3 - or 4 -hydroxy- $\beta$-carotene, is undoubtedly, as far as man is concerned, the most important provitamin next to $\beta$-carotene because of its occurrence in significant quantities in plants. As it has only one $\beta$-ionone ring intact, it has the same activity as $\alpha$-carotene, but Johnson \& Baumann (1948) found that it was as effective for deposition of vitamin $A$ in the liver as $\beta$-carotene though it had only half the activity of $\beta$-carotene when assayed by the growth method. Because of the hydroxyl group, it often occurs as the ester.

Myxoxanthin occurs in freshwater and marine algae and is a provitamin (Karrer $\&$ Rutschmann, 1944). Other biologically active carotenoids are echinenone and aphanin. Lutein $\left(3,3^{\prime}\right.$-hydroxy- $\alpha$-carotene $)$ is biologically inactive, but Zechmeister $\&$ Petracek (1956) showed that on treatment with acids three breakdown products are formed, one of which is a provitamin. Recently, Budowski, Ascarelli, Gross \& Nir (I963) have suggested that this compound is $3^{\prime}$-hydroxy-3,4-dehydro- $\beta$-carotene (anhydrolutein) and that it acts as a precursor of vitamin $A_{2}$ in the chick. It is possible that such compounds are formed in the preparation of food and animal feeds, e.g. in silage. Finally, astaxanthin $\left(\mathrm{C}_{40} \mathrm{H}_{52} \mathrm{O}_{4}\right)$ has been claimed to be a provitamin for fish (Grangaud \& Massonet, 1950). Although this is unlikely, if it were true the presence of the pigment in considerable amounts in a wide range of crustaceans would make it an important source of vitamin $\mathrm{A}$ in the marine food chain.

Cis-trans isomerism. Molecules with structures such as the carotenoids can exist in several spatial forms. Gilham \& El Ridi (I935) first drew attention to the problem. It was studied at great length by Zechmeister, Le Rosen, Schroeder, Polgar \& Pauling (1943). Bending of the molecule only occurs at those double bonds in the central chain adjacent to a methyl group. Zechmeister (1949) then showed that the all-trans forms predominate in nature and have twice the biological activity of the corresponding cis forms.

\section{Occurrence of the provitamins in plants and animals}

This subject was reviewed comprehensively by Goodwin (1952).

Plants. Carotenoids are found in all green tissues of plants and are associated with chlorophyll in the chloroplasts, probably as water-soluble protein complexes and sometimes in lipid droplets. In green leaves, although xanthophylls predominate, $\beta$-carotene is always present. In fifty-nine species studied by MacKinney (1935) the range was $200-700 \mu \mathrm{g} \beta$-carotene/g dry matter. Forty of these species contain $\alpha$-carotene as well in amounts varying from a trace to $35 \%$ of the total carotene fraction. In fruits, although the preponderant leaf carotenoids, $\beta$-carotene and lutein, do occur, they are often minor constituents; for instance, either $\alpha$ - or $\gamma$-carotene or lycopene 
Table 1. Proportion ( $\mathrm{mg} / \mathrm{1} 00 \mathrm{~g}$ fresh weight) of carotenoids in the more important sources of provitamins $A$ for man and his livestock

\begin{tabular}{|c|c|c|c|c|c|c|}
\hline \multirow[b]{2}{*}{ Source } & \multicolumn{2}{|c|}{ Carotene } & \multirow[b]{2}{*}{ Lycopene } & \multirow[b]{2}{*}{ Cryptoxanthin } & \multirow[b]{2}{*}{ Xanthophylls } & \multirow[b]{2}{*}{ Reference } \\
\hline & $\beta$ & $\alpha$ & & & & \\
\hline Grass & 8 & Trace & - & 一 & 16 & $\begin{array}{l}\text { Kon \& 'Thompson } \\
\text { (1940) }\end{array}$ \\
\hline Carrots & $7 \cdot 6$ & $4 \cdot 8$ & - & 一 & $I \cdot 4$ & Dark \& Booth (1946) \\
\hline Peas & 0.3 & - & 一 & - & 0.6 & Booth (I945) \\
\hline Potatoes & 0.006 & - & - & - & 0.04 & $\begin{array}{l}\text { Thompson } \\
\text { (I94I, unpublished) }\end{array}$ \\
\hline Sweet potatoes & $2 \cdot 0$ & - & 一 & - & Trace & Ezell \& Wilcox (1948) \\
\hline Tomatoes & 0.5 & - & 9 & 一 & Trace & $\begin{array}{l}\text { Kuhn \& Grundmann } \\
\text { (1932) }\end{array}$ \\
\hline Maize & 0.3 & 0.02 & - & 0.55 & $2 \cdot 6$ & $\begin{array}{l}\text { Sadana \& Ahmad } \\
\text { (1946a) }\end{array}$ \\
\hline Mangoes & 0.14 & - & - & - & 0.14 & $\begin{array}{c}\text { Sadana \& Ahmad } \\
(1946 b)\end{array}$ \\
\hline Water melons & 0.05 & 一 & 0.6 & - & 0.1 & $\begin{array}{l}\text { Zechmeister \& } \\
\text { Polgar (I94I) }\end{array}$ \\
\hline Pumpkins & 0.7 & - & - & - & - & Fraps (1947) \\
\hline Bananas & $0 \cdot 3$ & - & - & - & 0.2 & $\begin{array}{l}\text { Sadana \& Ahmad } \\
\quad(\text { I } 949 b)\end{array}$ \\
\hline Red-palm oil & 38 & 20 & - & 一 & - & Hunter \& Scott (1944) \\
\hline Oranges & 0.15 & - & - & 0.8 & $1 \cdot 3$ & $\begin{array}{l}\text { Sadana \& Ahmad } \\
\qquad(1948)\end{array}$ \\
\hline
\end{tabular}

is often the predominant carotenoid. Table I shows the proportions of carotenoids in some of the more important sources of provitamins A for man and his livestock. Although in many laboratories a large number of plant foods have been analysed as sources of provitamins $A$ for man, the values given are generally the findings in terms of 'carotene' and do not give information about the proportion of the provitamins and other carotenoids (see, for instance, for food eaten in USA Fraps (1947) and in Central America (Guatemala) Munsell, Williams, Guild, Kelley, McNally \& Harris (1950)). On the other hand, careful studies of the proportions of the carotenoids have been made on many plants, but they are not necessarily representative of the foods going into consumption as these investigations are often made in great detail on only one sample. For instance, the batch of water melons studied by Zechmeister \& Polgar (I94I) had the carotenoid distribution given in 'Table I, but Fraps (1947) found a mean carotene content ten times greater for the many samples he studied. Clearly, variety and stage of maturity alter the value widely. Table I shows that the most important sources of provitamins are grass, carrots, maize, sweet potatoes and red-palm oil. The carotenoid content of many fruits increases on storage, for instance in mangoes (Sadana \& Ahmad, I949a; Chaudhary, 1950) and in tomatoes (Ellis \& Hamner, I 943).

Lichens are a source of provitamins for reindeer, an important domestic animal in Lapland (Ellis, Palmer \& Barnum, I933). Fungi are generally devoid of carotenoids, but it is interesting to note that the carotenoid torularhodin $\left(\mathrm{C}_{37} \mathrm{H}_{48} \mathrm{O}_{2}\right)$ isolated by Karrer \& Rutschmann (1946) from the red yeast Rhodotorula rubra has vitamin A activity. Probably more is known about carotenogenesis in the fungi that do contain carotenoids than in any other plants (cf. Goodwin \& Wilmer, 1952). 
Animals. There is little doubt that animals do not synthesize carotenoids de novo but acquire them from their food either directly from plants or indirectly from animal sources, or produce carotenoids characteristic for the animal species by altering those in their food. Crustaceans contain traces of $\beta$-carotene, large amounts of astaxanthin, and also preformed vitamin A (Kon \& Thompson, 1949). Astaxanthin is often present as a protein complex, as in the lobster (Lwoff, 1925). Fish feed on zooplankton; they are capable of converting any $\beta$-carotene available (Morton $\&$ Creed, 1939), but may get most of their vitamin A preformed (from crustaceans, cephalopods, other fish). The skin and other tissues of fish are sometimes coloured, but the pigments in the edible parts are not provitamins; for instance, in salmon (Emmerie, van Eekelen, Josephy \& Wolff, 1934) and trout (Steven, 1948) the flesh is coloured by astaxanthin.

Insects are not often thought of as food, but an entertaining paper by Bristowe (1953) shows that they are quite important in the Far East. In the Middle East locusts have been included in the diet since biblical times; they contain IO-I $5 \mu \mathrm{g}$ $\beta$-carotene/g fresh weight (Goodwin, 1949).

Mammals can be divided into three groups according to whether they accumulate in the fatty tissues of the body (I) a mixture of carotenoids, (b) predominantly carotenes, or (c) no carotenoids (Goodwin, I952). Man falls in the first category, for the blood, milk and many organs contain, in addition to carotenes, lycopene, an unknown pigment and lutein (Kon \& Mawson, 1950). Cattle are the most important example of the second group. Palmer \& Eckles (1914) first noted the preferential accumulation of carotene in the tissue of cows. However, this depends to some extent on breed and diet, for Thompson, Henry $\&$ Kon (1964) found that the percentage of active carotene in milk in Great Britain was around 80 in summer and 68 in winter. In winter in Scotland, cows eat yellow turnips, a source of lycopene, and the milk-fat carotenoids contain occasionally only $25 \%$ carotenes (Thompson \& Kon, 1950). The horse, Indian buffalo, deer, antelope, water-buffalo, guinea-pig and hedgehog also come in this group. The sheep, dog and elephant sometimes have traces of carotenes as the only carotenoid (for more detailed information see Goodwin, I952). In the last group are the goat, pig, rat, rabbit, hare (Goodwin, I952), giraffe (Aschaffenburg, Gregory, Rowland, Thompson \& Kon, 1962) and reindeer (Aschaffenburg, Gregory, Kon, Rowland \& Thompson, 1962). Birds, like mammals, can convert provitamins into vitamin A, but they store preferentially xanthophylls. However, Steinegger, Streiff \& Zeller (I957) showed that the hen is capable of passing to the egg a surprising number of oxygenated carotenoids including $\beta$-apo-8-carotenal which has vitamin A activity as well as colouring powers. Wald \& Zussman (1938) found that hens can absorb astaxanthin, and Fox (1962) has shown that the pigments of the American and West Indian flamingo are mainly canthaxanthin, with some astaxanthin and numerous oxidation products of carotenoids not yet completely characterized.

\section{Sources of provitamin $A$ in man's diet in different parts of the world}

Since the introduction of vitamin $A$ acetate as the international standard for vitamin 
$\mathrm{A}$, it is agreed that $\mathrm{I} \mu \mathrm{g}$ retinol has an activity of $3.33 \mathrm{i}$.u. (World Health Organization, $195^{\circ}$ ). It is also agreed that $0.6 \mu \mathrm{g}$ all-trans $\beta$-carotene has the activity of $\mathrm{I}$ i.u. preformed vitamin $\mathrm{A}$ when the test is done at the low level used in the rat-growth method (League of Nations: Second Conference on Vitamin Standardisation, 1934), but for practical purposes, because of low digestibility, absorption or utilization, this conversion rate has to be lowered, and in this country McCance \& Widdowson (I960) divide the i.u. calculated in this way by 3 and the (USA) National Research Council (1964) in America divide by 2. In Britain (British Medical Association, 1950) and in America (National Research Council, 1964) it is agreed that adults need about 3000 i.u. of preformed vitamin A daily or two to three times this amount as provitamin A.

Europe. In Britain the foods going into consumption supplied in I962 4300 i.u. vitamin A activity daily per head (Ministry of Agriculture, Fisheries and Food: National Food Survey Committee, r964: Appendix C). Of this total, I I30 i.u. was from provitamins in vegetables, fruits and cereals and another 290 i.u. from provitamins in dairy produce; hence about $33 \%$ of the total vitamin A intake is supplied as provitamins. During the war the contribution from provitamins was around $44 \%$. The carrot supplied $68 \%$ of our carotene from vegetables and the tomato $72 \%$ of that from fruits (Table 2). In southern Europe melons, persimmons and pumpkins would contribute additionally or replace some of the sources listed in the table.

Table 2. The importance of vegetables and fruits as sources of provitamins $A$ in Great Britain

Vegetable or fruit

Brussels sprouts

Cabbages

Carrots

Lettuces

Peas and green beans

Dried, canned and others

Apples

Pears $\}$

Citrus fruits

Bananas

Tomatoes

Other, stone and soft fruits and canned

Amount
consumed*
(g/head day)
9.2
20.0
11.2
4.9
15.3
35.1

29.0
17.0
14.7
17.0
32.5

Contribution

to intake (i.u./head day)

*Ministry of Agriculture, Fisheries and Food: National Food Survey Committee (1964). †McCance \& Widdowson (1960).

Some data of Aykroyd \& Sukhatme (1960) were used to prepare Table 3. It reflects the big differences in feeding habits in the European countries listed. For instance, the Finns eat one-sixth the amount of vegetables and over three times the amount of milk consumed by the French.

North and South America. More detailed information is available for the United States than for any of the other countries. In the United States the general feeding 
Table 3. Yearly consumption (kg/head) of some foods in different parts of the world

\begin{tabular}{ll}
\multicolumn{2}{c}{ Country } \\
Europe: & Finland \\
& France \\
& Germany \\
& Greece \\
& United Kingdom \\
& United States \\
America: & Brazil \\
& Egypt \\
Africa: & South Africa \\
Middle East: & Israel \\
Far East: & China \\
& India \\
& Japan
\end{tabular}

$\begin{array}{cccc}\begin{array}{c}\text { Sweet } \\ \text { potato }\end{array} & \text { Vegetables } & \text { Fruits } & \text { Meat } \\ 0 & 19 & 32 & 33 \\ 0 & 132 & 48 & 69 \\ 0 & 45 & 70 & 48 \\ 0 & 92 & 95 & 18 \\ 0 & 59 & 43 & 54 \\ 3 \cdot 3 & 98 & 82 & 82 \\ 0 & 27 & 110 & 30 \\ 1.9 & 62 & 64 & 13 \\ 1 \cdot 7 & 38 & 30 & 43 \\ 0 & 116 & 110 & 21 \\ 65 & 58 & 15 & 17 \\ 3 \cdot 3 & 16 & 12 & 1.5 \\ 28 & 67 & 16 & 3.2\end{array}$

Adapted from Aykroyd \& Sukhatme (I960); mean values for i954-7.

Table 4. Comparison of food consumption and vitamin A intake in Great Britain and the United States

\begin{tabular}{|c|c|c|c|c|}
\hline Food & lb/week & i.u./day & lb/week & i.u./day \\
\hline $\begin{array}{l}\text { Milk } \\
\text { Cheese }\end{array}$ & $\left.\begin{array}{l}6.22 \\
0.20\end{array}\right\}$ & 674 & $8 \cdot 4$ & I344 \\
\hline Meat & $2 \cdot 40$ & 959 & 3.8 & 1919 \\
\hline Fish & $0 \cdot 36$ & 13 & & \\
\hline Eggs & 0.59 & 334 & $x \cdot 0$ & 622 \\
\hline Butter & 0.39 & 754 & 0.2 & 098 \\
\hline Margarine & 0.20 & 387 & $0.2\}$ & 990 \\
\hline Sugar and jams & $\mathrm{I} \cdot 35$ & - & $\mathrm{I} \cdot 3$ & - \\
\hline Vegetables & $5 \cdot 3$ & 830 & $7 \cdot 6$ & 4475 \\
\hline Fruits & 1.8 & 236 & $5 \cdot 1$ & 656 \\
\hline Cereals & $4 \cdot 30$ & 61 & 3.0 calc. & 64 calc. \\
\hline $\begin{array}{c}\text { Beverages and other foods } \\
\text { Total }\end{array}$ & 0.24 & $\begin{array}{r}52 \\
4306\end{array}$ & - & $\begin{array}{r}77 \\
\text { 10 } 55\end{array}$ \\
\hline
\end{tabular}

*Ministry of Agriculture, Fisheries and Food: National Food Survey Committee (1964). †United States Department of Agriculture (1957).

pattern is the same as in Europe, but Table 4 shows that the total vitamin A intake (10 200 i.u. daily) is two and a half times that in Great Britain, and that over $50 \%$ of it comes from vegetable sources; the consumption of dairy produce (excluding butter) and of fruit and vegetables is much greater than in Britain. The sweet potato provides one-tenth of the provitamin A from vegetable sources. Other important sources, not eaten in such large amounts in Britain, are sweetcorn, pumpkins, spinach, squashes, apricots, peaches, avocado pears, melons, water melons and yellow maize. In sharp contrast, Eskimoes in 1855 , according to calculations made by Sinclair (1953), were almost carnivorous; their intake per head daily of preformed vitamin $A$ was about Io 000 i.u., mainly from seal flesh. Their only vegetable source, berries, supplied I 5 i.u. provitamin A daily. 
Probably typical of the situation that can be found in many parts of Central and South America is that in Guatemala described by Flores, García, Flores \& Lara (I964), where not only does the diet supply often far less than the recommended allowance of vitamin A for adults, but $93 \%$ comes from provitamins and of this $34 \%$ from yellow maize.

Africa. The outstanding source of provitamin A on this continent is red-palm oil. As Table I shows, it is a very rich source of vitamin A activity. In western Nigeria the intake of $100-200 \mathrm{~g}$ of this oil supplies $60000-\mathrm{r} 20000 \mathrm{i} . \mathrm{u}$. daily, and this remarkably high intake causes the blood serum to be unusually rich in carotene (Carter 8 Cook, 1963). A part from carrots and maize, other important sources are sweet potatoes, fresh leaves, red paprikas, cape gooseberries, paw-paws and mangoes. Despite these rich sources of provitamins, vitamin A deficiency is prevalent in many parts of Africa (Nicol, 1949; Roels, Trout \& Dujaquier, 1958). Aykroyd \& Sukhatme (1960) give food consumption data for only two countries in Africa, Egypt and South Africa; Table 3 shows that the intake of cereals in these countries is high, which is probably true for many parts of the African continent.

The Middle East. Table 3 shows that in Israel the diets are better balanced than in Africa or the Far East.

The Far East. In many parts of India, particularly the south, little meat and milk are eaten and very little vegetables and fruits. The diets, mainly of cereals such as millet, rice, wheat or tapioca, supply less vitamin $A$ activity than the recommended allowance. A typical diet in the state of Mysore (Subrahmanyan, Narayanarao, Ramarao \& Swaminathan, I955) supplied only ıoo i.u. daily (mainly as carotene). Aykroyd (1944) said that Indians would have to increase their consumption of leafy vegetables six- to eight-fold to balance their diet. Other interesting differences in feeding habits in the East are seen in Table 3 , for instance the low milk consumption in China and Japan.

\section{Factors affecting the absorption and utilization of the provitamins}

Since there is no evidence so far that the provitamins can act as vitamin A per se, the interest is not so much in their absorption as such as in their potential yield of vitamin $\mathrm{A}$ after absorption and conversion.

Digestibility. Provitamins A are present in most foods; in the cells of plants they are as solutions in fats or as protein complexes (Strauss, 1942) or in crystalline forms. During passage through the digestive tract, first the plant cells must be broken down, and the presence of carotene in faeces in intact plant cells shows that this can be far from complete (Hume \& Krebs, I949). Then in the small intestine the provitamins can be (a) absorbed as such, (b) converted into vitamin A, or (c) destroyed by enzymes, bacteria or oxidation. Clearly the difference between the amounts of the provitamin in the food and in the faeces does not represent that converted into vitamin A, but such studies have shown that carotene is better utilized from oily solution than from vegetable sources (De, I937; Kemmerer \& Fraps, 1938).

Level of intake. A recent example of the poor utilization at high dose level is shown in Fig. I (from Thompson, 1963). In the cow, increasing the dose of $\beta$-carotene 

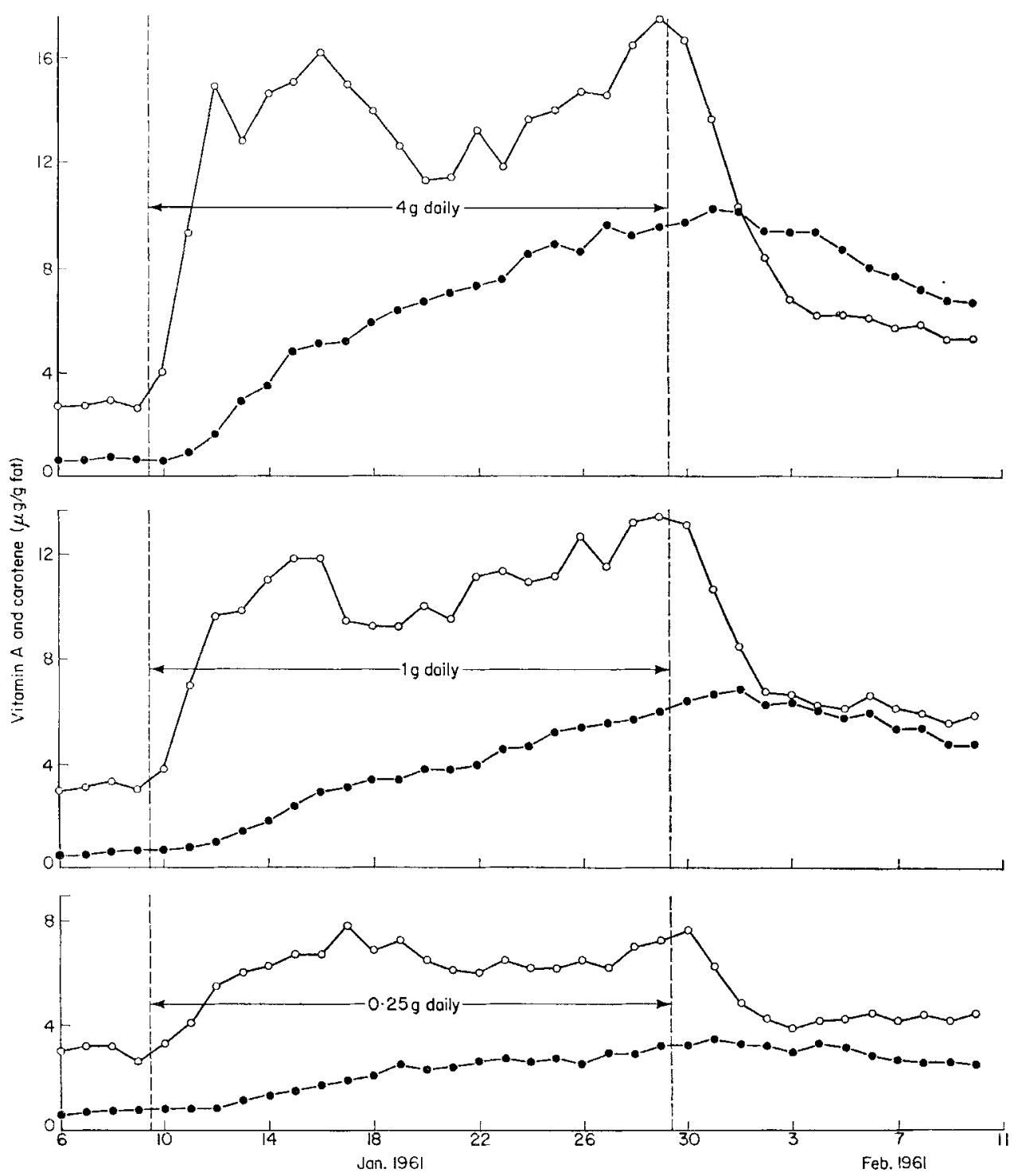

Fig. 1. Vitamin A and carotene in the milk fat of twelve Friesian cows on a carotene-low diet, supplemented during $2 \mathrm{I}$ days with $0.25, \mathrm{I} .0$ or $4.0 \mathrm{~g}$ carotene daily as a $14.5 \%$ microcrystalline gelatin beadlet preparation. Each point represents the mean value for four cows. $\circ-0$, vitamin $A$; $-\bullet$, carotene. (Thompson, 1963.)

fourfold produced a $2 \cdot 5$-fold increase in milk carotene and vitamin A content, and a sixteenfold increase in the dose produced only a fourfold increase.

Amount of dietary fat and state of dispersion. Animal experiments have shown the beneficial effect of fat in the utilization of provitamins, which has been shown to be true for man. Recently Roels et al. (1958) found that African boys receiving $200 \mathrm{~g}$ carrots in addition to their normal diet absorbed only $5 \%$ of the $24(2) 2$ 
carotene, but a supplement of $\mathrm{I} 8 \mathrm{~g}$ olive oil increased the absorption to $25 \%$ and produced large and rapid increases in serum content of carotene and vitamin A. However, carotene can be used in the absence of fat, either in aqueous colloidal dispersions or, better still, as dispersions with surface-active agents such as Tweens (Tomarelli, Charney \& Bernhart, 1946; Kon, McGillivray \& Thompson, 1955). Particle size is very important since the introduction of dry powder preparations. For instance, Thompson (1963) found that if the particles were less than $\mathrm{r} \mu \mathrm{m}$ the provitamin was very effectively utilized.

Nature of the dietary fat. An antagonism between the unsaturated fatty acids and vitamin $\mathrm{E}$ affects carotene metabolism (Sherman, 194I). The inclusion in the diets of fats that are poorly digested, such as paraffin oil or beeswax, lowers the utilization of carotene (McGillivray, 1957; McGillivray, Thompson \& Worker, 1958). The levels of tocopherol and lecithin also are important. For a brief review of other fatsoluble factors see Thompson (1964).

Nature and level of the dietary protein. Since the original report on the effect of protein intake on the utilization of provitamin A (Indian Council of Medical Research, 1952), there has been evidence to show that a diet low in protein, or containing poor-quality proteins, hinders the utilization of the provitamins (Arroyave, Béhar, Wilson, Mendez \& Scrimshaw, I959; Friend, Heard, Platt, Stewart \& Turner, I96r; Deshmukh, Malathi \& Ganguly, I964; Dietl, r963).

Other dietary factors. Cattle feeds containing much nitrite or nitrate have been blamed for lowering the vitamin A status of the animal (Pugh \& Garner, I963). Raw soya bean contains an enzyme that oxidizes fat and destroys carotene (Squibb, Cannon \& Allen, 1948). Since the original observations of von Euler \& Klussman (1932) of an antagonism between thyroxine and carotene affecting the growth of rats deficient in vitamin A, and of Fasold \& Heidemann ( 1933 ) that carotene appears in the otherwise colourless milk fat of the goat after thyroidectomy, there has been no aspect of carotene metabolism more controversial, and there is much evidence for and against such a relationship between carotene and thyroxine (cf. Moore, I957).

It is evident that many factors affect the utilization of preformed vitamin $A$, and that even more affect that of the provitamins. The chemical estimation of the provitamin tells the dietician which forms are present and in what amounts; after that, like the policeman in Gilbert \& Sullivan's Pirates of Penzance, his lot is not a happy one.

\section{REFERENCES}

Arroyave, G., Béhar, M., Wilson, D., Mendez, J. \& Scrimshaw, N. S. (1959). Fed. Proc. 18, 516.

Aschaffenburg, R., Gregory, M. E., Kon, S. K., Rowland, S. J. \& Thompson, S. Y. (1962). F. Dairy Res. 29, 325.

Aschaffenburg, R., Gregory, M. E., Rowland, S. J., Thompson, S. Y. \& Kon, V. (1962). Proc. zool. Soc. Lond. 139, 359.

Aykroyd, W. R. (1944). Indian Research Fund Association: Note on the Results of Diet Surveys in India. Cawnpore: The Job Press.

Aykroyd, W. R. \& Sukhatme, P. V. (1960). Food Supply, Time Series. Rome: Food and Agriculture Organization of the United Nations.

Booth, V. H. (1945). F. Soc. chem. Ind. 64, I62.

Bristowe, W. S. (1953). Proc. Nutr. Soc. 12, 44. 
British Medical Association (1950). Report of the Committee on Nutrition. London: British Medical Association.

Budowski, P., Ascarelli, I., Gross, J. \& Nir, I. (1963). Science, 142, 969.

Carter, R. A. \& Cook, G. C. (1963). Brit. F. Nutr. 17, 515.

Chaudhary, M. 'T. (1950). F. Sci. Fd Agric. I, I73.

Dark, S. O. S. \& Booth, V. H. (1946). F. agric. Sci. 36, 192.

De, N. K. (1937). Indian F. med. Res. 24, 751 .

Deshmukh, D. S., Malathi, P. \& Ganguly, J. (1964). Biochem. Y. 9o, 98.

Dietl, B. (1963). Roczn. Zakl. Hig., Warsz., r4, 259.

Ellis, G. H. \& Hamner, K. C. (1943). F. Nutr. 25, 539.

Ellis, N. R., Palmer, L. J. \& Barnum, G. L. (1933). 尹. Nutr. 6, 443.

Emmerie, A., van Eekelen, M., Josephy, B. \& Wolff, L. K. (r934). Acta brev. neerl. Physiol. 4, 139.

Ezell, B. D. \& Wilcox, M. S. (1948). Food Res. r3, 203.

Fasold, H. \& Heidemann, E. R. (1933). Z. ges. exp. Med. 92, 53.

Flores, M., García, B., Flores, Z. \& Lara, M. Y. (1964). Brit. F. Nutr. 18, 28 I.

Fox, D. L. (1 962). Comp. Biochem. Physiol. 6, I.

Fraps, G. S. (1947). Bull. Tex. agric. Exp. Sta. no. 690.

Friend, C. J., Heard, C. R. C., Platt, B. S., Stewart, R. J. C. \& Turner, M. R. (1961). Brit. F. Nutr. $\mathbf{5}, 231$.

Gershoff, S. N., Andrus, S. B. \& Hegsted, D. M. (1954). Fed. Proc. 13, $45^{8}$.

Gilham, A. E. \& El Ridi, M. S. (1935). Nature, Lond., 136, 9 I4.

Glover, J. \& Redfearn, E. R. (1954). Biochem. F. 58, isP.

Goodwin, T. W. (1949). Biochem. f. 45, 472.

Goodwin, T. W. (1952). The Comparative Biochemistry of the Carotenoids. London: Chapman \& Hall Ltd.

Goodwin, T. W. \& Wilmer, J. S. (1952). Biochem. 7. 51, 2 г 3.

Grangaud, R. \& Massonet, R. (1950). C. R. Acad. Sci., Paris, 230, 1319.

Hume, E. M. \& Krebs, H. A. (1949). Spec. Rep. Ser. med. Res. Coun., Lond., no. 264.

Hunter, R. F. \& Scott, A. D. (1944). Biochem. F. 38, 2 I.

Indian Council of Medical Research (1952). Rep. Indian Coun. med. Res.

Johnson, R. M. \& Baumann, C. A. (1948). Arch. Biochem. 19, 493.

Karrer, P., Jucker, E., Rutschmann, J. \& Steinlin, K. (1945). Helv. chim. acta, 28, 1146.

Karrer, P. \& Rutschmann, J. (1944). Helv. chim. acta, 27, 169 I.

Karrer, P. \& Rutschmann, J. (1946). Helv. chim. acta, 29, 355.

Karrer, P. \& Solmssen, U. (1937). Helv. chim. acta, 20, 682.

Kemmerer, A. R. \& Fraps, A. S. (1938). \%. Nutr. 16, 309.

Kon, S. K., McGillivray, W. A. \& Thompson, S. Y. (1955), Brit. F. Nutr. 9, 244.

Kon, S. K. \& Mawson, M. E. (1950). Spec. Rep. Ser. med. Res. Coun., Lond, no. 269.

Kon, S. K. \& Thompson, S. Y. (1940). F. agric. Sci. 30, 622.

Kon, S. K. \& Thompson, S. Y. (1949). Arch. Biochem. 24, 233.

Kuhn, R. \& Grundmann, C. (1932). Ber. dtsch. chem. Ges, 65, 1880

League of Nations: Second Conference on Vitamin Standardisation (1934). Quart. Bull. Hlth Org. 3, 428 .

Lwoff, A. (1925). C. R. Soc. Biol., Paris, 93, 1602.

McCance, R. A. \& Widdowson, E. M. (1960). Spec. Rep. Ser. med. Res, Coun., Lond., no. 297.

McGillivray, W. A. (1957). N.Z. F. Sci. Tech. A, 38,878.

McGillivray, W. A. (1961). Brit. F. Nutr. 15, 313.

McGillivray, W. A., 'Thompson, S. Y. \& Worker, N. A. (1958). F. Dairy Res. 25, 439.

MacKinney, G. (I935). F. biol. Chem. 11x, 75.

Marusich, W., De Ritter, E., Vreeland, J. \& Krukar, R. J. (1960). F. agric. Fd Chem. 8, 390.

Ministry of Agriculture, Fisheries and Food: National Food Survey Committee (1964). Domestic Food Consumption and Expenditure: 1962. London: HM Stationery Office.

Moore, T. (I957). Vitamin A. London: Elsevier Publishing Co.

Morton, R. A. \& Creed, R. H. (1939). Biochem. F. 33, 3 I8.

Munsell, H. E., Williams, I. O., Guild, L. P., Kelley, L. T., McNally, A. M. \& Harris, R. S. (1950). Food Res. 15, 439 .

National Research Council (1964). Publ, nat. Res. Coun., Wash., no. 1146.

Nicol, B. M. (1949). Brit. F. Nutr. 3, 25.

Palmer, L. S. \& Eckles, C. H. (1914). F. biol. Chem. 17, r9r.

Pugh, D. L. \& Garner, G. B. (1963). F. agric. Fd Chem. Ir, 528.

Roels, O. A., Trout, M. \& Dujaquier, R. (1958). F. Nutr. 65, I 15.

Sadana, J. C. \& Ahmad, B. (1946a). Indian $\mathcal{Y}$. med. Res. 34, 59.

Sadana, J. C. \& Ahmad, B. (1946b). Indian $¥$. med. Res. 34, 69. 
Sadana, J. C. \& Ahmad, B. (1948). F. sci. industr. Res. 7B, 96.

Sadana, J. C. \& Ahmad, B. (1949a). Indian F. med. Res. 37, 193.

Sadana, J. C. \& Ahmad, B. (1949b). F. sci. industr. Res. 8B, 35.

Sherman, W. C. (1941). Proc. Soc. exp. Biol., N.Y., 47, 199.

Sinclair, H. M. (1953). Proc. Nutr. Soc. 12, 69.

Squibb, R. L., Cannon, C. Y. \& Allen, R. S. (I948). F. Dairy Sci. 31, 42 I.

Steinegger, P., Streiff, K. \& Zeller, P. (1957). Mitt. Lebensm. Hyg., Bern, 48, no. 6.

Steven, D. M. (1948). F. exp. Biol. 25, 369 .

Strauss, W. (1942). Helv. chim. acta, 25, 705.

Subrahmanyan, V., Narayanarao, M., Ramarao, G. \& Swaminathan, M. (1955). Brit. I. Nutr. 9, 350.

Thompson, S. Y. (1963). In Carotine und Carotenoide, p. 263. [K. Lang, editor.] (Wissenschaftliche Veröffentlichungen der Deutschen Gesellschaft für Ernährung. Vol. 9.) Darmstadt: Dr Dietrich Steinkopff Verlag.

Thompson, S. Y. (1964). Exp. Eye Res. 3, 392.

Thompson, S. Y., Henry, K. M. \& Kon, S. K. (1964). J. Dairy Res. 31, I.

Thompson, S. Y. \& Kon, S. K. (1950). Congr. int. Sucr. Distill. vir1. Brussels, 2, 55.

Tomarelli, R. M., Charney, J. \& Bernhart, F. W. (1946). Proc. Soc. exp. Biol., N.Y., 63, 108.

United States Department of Agriculture (1957). Household Food Consumption Survey 1955. Reports no. $x$ and no. 6. Washington: US Government Printing Office.

von Euler, H. \& Klussman, E. (1932). Hoppe-Seyl. Z. 213, I 2.

Wald, G. \& Zussman, H. (1938). F. biol. Chem. r22, 449.

Winterstein, A., Studer, A. \& Rüegg, A. (1960). Chem. Ber. 93, 295 I.

World Health Organization (1950). Tech. Rep. Ser. Wld Hlth Org. no. 3.

Zechmeister, L. (I949). Vitam. E Horm. 7, 57.

Zechmeister, L., Le Rosen, A. I.., Schroeder, W. A., Polgar, A. \& Pauling, L. (1943). F. Amer. chem. Soc. $65,1940$.

Zechmeister, L. \& Petracek, F. J. (1956). Arch. Biochem. Biophys. 6r, 243.

Zechmeister, L. \& Polgar, A. (194I). F. biol. Chem. 139, 193.

\section{Occurrence, absorption and distribution of vitamin $A$}

By P. A. Plack*, Unit for Biochemical Research bearing on Fisheries' Problems $\dagger$, National Institute for Research in Dairying, Shinfield, Reading

Vitamin A itself is found in the animal kingdom together with carotenoid pigments, but plants are considered to contain carotenoid pigments but no preformed vitamin $A$. A possible exception is the small amount of the aldehyde form of vitamin A found by Winterstein \& Hegedüs (1960) in spinach and other plants; the concentrations present, of the order of $0 . \mathrm{I} \mu \mathrm{g} / \mathrm{g}$ fresh weight, are not of nutritional importance, and the aldehyde is possibly there as a minor metabolite of the carotenoid pigments.

With vitamin $A$ the occurrence and distribution are therefore closely related. By occurrence is meant here the presence in foodstuffs, particularly those of man, whereas distribution refers to the presence of vitamin $\mathrm{A}$ in different organs, tissues, cells and intracellular particles of man and other animals after its ingestion and absorption.

\section{Occurrence}

Forms of vitamin $A$. Some of the forms of vitamin $A$ that occur naturally are shown in Fig. I. The basic compound, retinol or vitamin $A_{1}$ alcohol, contains twenty carbon atoms arranged in a $\beta$-ionone ring with a side-chain of two isoprene units and a primary alcohol group. Five conjugated double bonds are present. A similar compound, dehydroretinol or vitamin $A_{2}$ alcohol, has two hydrogen atoms less in the

*Present address: Fisheries Biochemical Research Unit, St Kittick's Road, Aberdeen.

†Grant-aided by the Development Fund. 